Review

\title{
Modification of Insect and Arachnid Behaviours by Vertically Transmitted Endosymbionts: Infections as Drivers of Behavioural Change and Evolutionary Novelty
}

\author{
Sara L. Goodacre ${ }^{1, *}$ and Oliver Y. Martin ${ }^{2}$ \\ 1 School of Biology, University of Nottingham, NG7 2RD, UK \\ 2 ETH Zurich, Experimental Ecology, Institute for Integrative Biology, Universitätsstrasse 16, \\ CH-8092 Zurich, Switzerland; E-Mail: oliver.martin@env.ethz.ch \\ * Author to whom correspondence should be addressed; E-Mail: sara.goodacre@nottingham.ac.uk; \\ Tel.: +44-115-8230334.
}

Received: 29 January 2012; in revised form: 17 February 2012 / Accepted: 21 February 2012 / Published: 29 February 2012

\begin{abstract}
Vertically acquired, endosymbiotic bacteria such as those belonging to the Rickettsiales and the Mollicutes are known to influence the biology of their arthropod hosts in order to favour their own transmission. In this study we investigate the influence of such reproductive parasites on the behavior of their insects and arachnid hosts. We find that changes in host behavior that are associated with endosymbiont infections are not restricted to characteristics that are directly associated with reproduction. Other behavioural traits, such as those involved in intraspecific competition or in dispersal may also be affected. Such behavioural shifts are expected to influence the level of intraspecific variation and the rate at which adaptation can occur through their effects on effective population size and gene flow amongst populations. Symbionts may thus influence both levels of polymorphism within species and the rate at which diversification can occur.
\end{abstract}

Keywords: reproductive parasite; host; arthropod; manipulation; bacteria

\section{The Effects of Bacterial Endosymbionts on the Biology of Their Hosts}

The nature of the relationship between hosts and their parasites has been the focus of a wide range of studies (reviewed in [1]). One particular area of current interest is in the types of behavioural change 
that can be induced in a host following an infection. Studies of horizontally acquired nematode, trematode or protozoan parasites in a range of arthropods indicate that behavioural changes may be induced through altered levels of gene expression in the host CNS [2,3]. The precise mechanisms are not fully understood but in many instances the behavioural change is predicted to be the consequence of selection acting on the parasite to promote its own transmission. Behavioural changes are also induced in hosts following infection with vertically acquired, intracellular bacteria such as Wolbachia, Cardinium or Spiroplasma. These changes in host biology may also be driven by selection acting to promote bacterial transmission, but in this case the primary route is from mother to offspring. Horizontal transmission, whilst it undoubtedly occurs, is not the primary transmission route for these bacteria [4] and is therefore likely only to be important on an evolutionary timescale.

There are several main intracellular, primarily vertically acquired, bacterial lineages that are known to infect arthropods. These include bacteria from the Rickettsiales such as Wolbachia, and Rickettsia, members of the Bacteroidetes group such as Cardinium or Flavobacteria, Mollicutes such as Spiroplasma and Arsenophonus, a newly described bacterium lineage belonging to the Gamma-Proteobacteria. Each of these is inherited primarily through the female germ line and as such is always found within female reproductive tissue, but many are found within a much wider range of host tissue types and/or are present throughout the haemocoel. These bacteria act as selfish genetic elements, promoting their own transmission by increasing the reproductive success of infected females. They achieve this through a variety of mechanisms: (1) by causing cytoplasmic incompatibility (where uninfected females produce no offspring when mating with an infected male) (2) by biasing the sex ratio in favour of females via either male-killing (either early or late, i.e., as embryos or as larvae) or through feminisation of genetically male individuals or (3) through inducing parthenogenesis [4,5]. A summary of bacterial phenotypes and examples of taxa in which these have been found is given in Table 1. Thus far only Wolbachia has been shown to cause all these phenotypes, whereas for Cardinium there is evidence for all of these phenotypes except male-killing. In contrast, the other microbes are all known to act as male-killers and Rickettsia can also be associated with parthenogenesis.

Table 1. Overview of the classic symbiont-induced phenotypes with responsible microbes and examples of known insect and arachnid host taxa in which they occur.

\begin{tabular}{lll}
\hline Phenotype & \multicolumn{1}{c}{ Symbiont } & \multicolumn{1}{c}{ Host taxa (references) } \\
\hline Male-killing & & \\
\hline & Wolbachia & Lepidoptera: Nymphalidae: Hypolimnas bolina [30], Acraea encedon [33] \\
& & Pseudoscorpiones: Chernetidae: Cordylochernes scorpioides [34] \\
& Araneae: Linyphiidae: Oedothorax gibbosus [35] \\
& Rickettsia & Coleoptera: Buprestidae: Brachys tessellates [36] \\
& Coleoptera: Coccinellidae: Adalia bipunctata [37], \\
& Adalia decempunctata [38] \\
& Coleoptera: Coccinellidae: Adalia bipunctata [39], \\
& Axodetis & Anisosticta novemdecimpunctata [40], Harmonia axyridis [41] \\
& Lepidoptera: Nymphalidae: Danaus chrysippus [42] \\
& S. poulsonii & Diptera: Drosophilidae: Drosophila willistoni group [43]
\end{tabular}


Table 1. Cont.

\begin{tabular}{lll}
\hline Phenotype & \multicolumn{1}{c}{ Symbiont } & \multicolumn{1}{c}{ Host taxa (references) } \\
\hline Male-killing & & \\
& $\begin{array}{l}\text { Arsenophonus } \\
\text { nasoniae } \\
\text { Flavobacterium } \\
\text { sp. }\end{array}$ & Hymenoptera: Pteromelidae: Nasonia vitripennis [44] \\
& Coleoptera: Coccinellidae: Coleomegilla maculata [45], \\
Adonia variegata [46]
\end{tabular}

Vertically acquired bacterial symbionts are extremely common in arthropods, with the most intensively studied bacterium in this context, Wolbachia, potentially infecting more than $60 \%$ of insect species [6]. Although Wolbachia could well represent the most widespread symbiont in insects, various surveys of insects and arachnids show that other symbiont types may also be highly prevalent [7-9]. Some strains, such as Cardinium, appear to be more common in arachnids than in insects, an observation that indicates that individual bacterial types do not infect all arthropod groups equally $[10,11]$.

The wide range of hosts that can be infected with symbionts such as Wolbachia is matched by a correspondingly wide range of known additional effects on host physiological and fitness traits such as female fecundity and male fertility (Table 2). Although the physiological consequences of an endosymbiont infection in any given species are not always fully understood it is clear that these bacteria can interfere in a diverse range of processes and in some cases may even be essential to host survival or reproduction. For example the presence of Wolbachia has been shown to be necessary for host oogenesis in the hymenopteran parasitoid Asobara tabida [12]. Similar effects are known from associations between symbionts and their nematode hosts. Physiological effects are however not restricted to reproductive processes; symbionts may also alter host susceptibility to a range of biotic 
and abiotic factors (summarised in Table 2). For example, some bacteria have been shown to provide benefits to their host through conferring increased resistance to pathogens, elevating protection from parasitoids, altering susceptibility to insecticides and improving thermotolerance. These kinds of beneficial effects are perhaps not unexpected given that bacterially mediated resistance against pathogens and parasitoids is already known from studies of other types of bacteria to those that are the focus of this study. For example, the Hamiltonella defensa bacterial symbiont that infects the pea aphid Acyrthosiphon pisum can block larval development of the hymenopteran parasitoids Aphidius ervi, A. eadyi [13] and Lysiphlebus fabarum [14].

Table 2. Physiological effects of infection with vertically acquired, endosymbiotic bacteria in arthropod hosts.

\begin{tabular}{|c|c|c|c|}
\hline Traits & Effects & Symbionts & Host species (references) \\
\hline \multicolumn{4}{|l|}{ Reproduction } \\
\hline Female fecundity & $\begin{array}{l}\text { Infection decreases offspring } \\
\text { number }\end{array}$ & Wolbachia & Tribolium confusum [67] \\
\hline Female fecundity & Infection increases fecundity & Cardinium & Metaseiulus occidentalis [68] \\
\hline “ & “ & Wolbachia & Trichogramma bourarachae [69] \\
\hline “ & “ & Wolbachia & Aedes albopictus [70] \\
\hline Fertilization & $\begin{array}{l}\text { No participation of sperm in } \\
\text { reproduction of infected females }\end{array}$ & Wolbachia & Telenomus nawai [54] \\
\hline $\begin{array}{l}\text { Microbe necessary } \\
\text { for host oogenesis }\end{array}$ & $\begin{array}{l}\text { Bacterium influences programmed } \\
\text { cell death processes, so presence is } \\
\text { essential for maturation of host } \\
\text { oocytes }\end{array}$ & Wolbachia & $\begin{array}{l}\text { Parasitoid wasp } \\
\text { Asobara tabida [12] }\end{array}$ \\
\hline “ & $\begin{array}{l}\text { Females treated with tetracycline } \\
\text { or rifampicin have significantly } \\
\text { reduced number of mature eggs in } \\
\text { their ovaries }\end{array}$ & Wolbachia & Drosophila paulistorum [71] \\
\hline Male fertility & Infection increases fertility & Wolbachia & Tribolium confusum [67] \\
\hline $\begin{array}{l}\text { Sperm competitive } \\
\text { ability }\end{array}$ & $\begin{array}{l}\text { Infection leads to reduced sperm } \\
\text { competition success }\end{array}$ & Wolbachia & Drosophila simulans [72] \\
\hline \multicolumn{4}{|l|}{ Immunity } \\
\hline $\begin{array}{l}\text { Resistance } \\
\text { (fungus) }\end{array}$ & $\begin{array}{l}\text { Infected females are more resistant } \\
\text { to the entomopathogenic fungus } \\
\text { Beauveria bassiana } \\
\text { Infection induces resistance to }\end{array}$ & Wolbachia & Drosophila melanogaster [73] \\
\hline $\begin{array}{l}\text { Resistance } \\
\text { (viruses) }\end{array}$ & $\begin{array}{l}\text { Dengue virus and infected } \\
\text { mosquitoes are less likely to } \\
\text { transmit the disease }\end{array}$ & Wolbachia & Aedes aegypti [74] \\
\hline “ & $\begin{array}{l}\text { Infection increases host resistance } \\
\text { to Drosophila } \mathrm{C} \text { virus (DCV) }\end{array}$ & Wolbachia & Drosophila melanogaster [74] \\
\hline
\end{tabular}


Table 2. Cont.

\begin{tabular}{|c|c|c|c|}
\hline Traits & Effects & Symbionts & Host species (references) \\
\hline \multicolumn{4}{|l|}{ Reproduction } \\
\hline “ & $\begin{array}{l}\text { Infected individuals more resistant } \\
\text { to mortality induced by the viruses } \\
\text { DCV, cricket paralysis virus, } \\
\text { Flock House virus }\end{array}$ & Wolbachia & Drosophila melanogaster [75] \\
\hline “ & $\begin{array}{l}\text { Antiviral protection occurs in } \\
\text { some yet not all fly line- } \\
\text { Wolbachia strain combinations } \\
\text { assessed }\end{array}$ & Wolbachia & Drosophila simulans [77] \\
\hline \multicolumn{4}{|l|}{ Fitness } \\
\hline Survival & Infection increases longevity & Wolbachia & $\begin{array}{l}\text { Drosophila melanogaster [78], } \\
\text { Aedes albopictus [70] }\end{array}$ \\
\hline $\begin{array}{l}\text { Nutritional } \\
\text { mutualism }\end{array}$ & $\begin{array}{l}\text { Infections required for host } \\
\text { function, probably via provision of } \\
\text { B vitamins missing in the diet the } \\
\text { blood-feeding host }\end{array}$ & $\begin{array}{l}\text { Riesia } \text { sp. } \\
\text { ('biologically highly } \\
\text { derived species of } \\
\text { Arsenophonus' [79]) }\end{array}$ & $\begin{array}{l}\text { Pediculus and Pthirus } \\
\text { species of lice }[80,81]\end{array}$ \\
\hline “ & $\begin{array}{l}\text { Symbiont has essential nutritional } \\
\text { role for the host (B vitamins) }\end{array}$ & Wolbachia & Cimex lectularius [82] \\
\hline $\begin{array}{l}\text { Metabolic } \\
\text { provisioning }\end{array}$ & $\begin{array}{l}\text { Benefit apparent under nutritional } \\
\text { stress: if flies reared on poor diets, } \\
\text { infected flies produce more eggs } \\
\text { than uninfected flies }\end{array}$ & Wolbachia & Drosophila melanogaster [83] \\
\hline Thermotolerance & $\begin{array}{l}\text { When compared to uninfected } \\
\text { population, infected population } \\
\text { had significantly increased } \\
\text { tolerance to heat shock that } \\
\text { reached } 40{ }^{\circ} \mathrm{C}\end{array}$ & Rickettsia & Bemisia tabaci [84] \\
\hline $\begin{array}{l}\text { Protection against } \\
\text { parasitoid }\end{array}$ & $\begin{array}{l}\text { Infection enhances survival of } \\
\text { individuals attacked by parasitic } \\
\text { wasp (i.e., possible defensive } \\
\text { mutualism) }\end{array}$ & Spiroplasma & Drosophila hydei [85] \\
\hline $\begin{array}{l}\text { Susceptibility } \\
\text { to insecticides }\end{array}$ & $\begin{array}{l}\text { Infected individuals more } \\
\text { susceptible }\end{array}$ & $\begin{array}{l}\text { Rickettsia } \\
\text { double infections }\end{array}$ & Bemisia tabaci [86] \\
\hline $\begin{array}{l}\text { Susceptibility } \\
\text { to insecticides }\end{array}$ & $\begin{array}{l}\text { Infected individuals more } \\
\text { susceptible }\end{array}$ & $\begin{array}{l}\text { Rickettsia- } \\
\text { Arsenophonus \& } \\
\text { Wolbachia- } \\
\text { Arsenophonus }\end{array}$ & Bemisia tabaci $[85,86]$ \\
\hline
\end{tabular}


It is known that the speed at which phenotypic changes in the host can be effected by endosymbionts may be rapid [15] and it is also known that bacterial phenotypes have the potential to change [16]. Features of the bacterial genomes themselves may play a part in the latter, for instance mobile genetic elements and the presence of numerous phage are proposed to contribute to the rate at which the phenotype that is induced in the host changes from one state to another, for example from pathenogenicity to protective mutualism [13]. There is clearly, however, also a role for the interaction between host and bacterial genomes in determining phenotype because the same type of symbiont can cause different effects in different hosts. As an example, Spiroplasma causes male-killing in several Drosophila species, yet other spiroplasmas, such as that which infect the pea aphid, Acyrthosiphon pisum [17], are not male-killers. In fact, even the same bacterial strain need not always have the same effects. This is illustrated in Table 3, which lists a range of different phenotypes exerted by identical Wolbachia strains infecting different hosts. A single infecting strain may even cause different phenotypes depending upon its precise location within the host. For example the effect of the same infecting Rickettsia strain in whiteflies is shown to be dependent upon whether it is found widely throughout the host's hemocoel or if it is restricted to within bacteriocytes [18].

Table 3. Wolbachia strains known to cause different phenotypes or effects in different hosts.

\begin{tabular}{lll}
\hline Taxonomy, references & \multicolumn{1}{c}{ Host species } & \multicolumn{1}{c}{ Phenotype induced } \\
\hline Diptera: & Drosophila recens (natural host) & CI \\
Drosophilidae [16] & Drosophila subquinaria (introgressed) & Male-killing (in some host strains) \\
Lepidoptera: & Cadra cautella (natural host) & CI (partial) \\
Pyralidae [88] & Ephestia kuehniella (transinfected) & Male-killing \\
& (a) Chaetophiloscia elongata (natural host) & Feminization \\
Isopoda: Philosciidae, & (a) Armadillidium vulgare (transinfected) & No feminization of males \\
Armadillidiidae & (b) Armadillidium vulgare (natural host) & Feminization \\
and Onscidae [89] & (b) Armadillidium nasatum (transinfected) & Feminization \\
& (b) Oniscus asellus (transinfected) & No feminization of males \\
Coleoptera: & Tribolium confusum (natural host) & CI \\
Tenebrionidae [90] & Tribolium madens (natural host) & Male killing \\
\hline
\end{tabular}

\section{Endosymbionts as Direct and Indirect Sources of Behavioural Change}

In addition to the physiological effects already described (Tables 1-3) it is known that vertically acquired endosymbiont infections can result in altered behaviour of the infected host. A summary of the types of behavioural shifts that have been observed thus far is given in Table 4. The types of change that are documented can be grouped into 'reproductive behaviour' (i.e., those behaviours directly involved in reproduction) and non-reproductive behaviour (i.e., those not directly involved in reproduction). Reproductive behaviours that are known to be directly under the influence of endosymbiont infections include mating preference, courtship, mating duration, mating frequency and post-mating behaviours of females such as oviposition. Non-reproductive behaviours, which are less frequently reported in the literature as being influenced by endosymbiont infections than reproductive behaviours, include dispersal in a linyphiid spider [19] and competitive behaviour of larvae in Drosophila [20]. 
Table 4. Behavioural effects of infection with vertically acquired, endosymbiotic bacteria in arthropod hosts.

\begin{tabular}{|c|c|c|c|}
\hline Behaviour & Effects & Symbionts & Host species (reference) \\
\hline \multicolumn{4}{|l|}{ Reproductive } \\
\hline $\begin{array}{l}\text { Female mating } \\
\text { behaviour }\end{array}$ & $\begin{array}{l}\text { Pre-mating isolation via selective mate } \\
\text { avoidance, i.e., avoiding mates harboring } \\
\text { another, incompatible symbiont variant. }\end{array}$ & Wolbachia & $\begin{array}{l}\text { Drosophila } \\
\text { paulistorum [71] }\end{array}$ \\
\hline “ & $\begin{array}{l}\text { Females of thelytokous host strain } \\
\text { inseminated less often than arrhenotokous } \\
\text { (sexual) females. }\end{array}$ & Wolbachia & $\begin{array}{l}\text { Apoanagyrus } \\
\text { diversicornis [55] }\end{array}$ \\
\hline “ & $\begin{array}{l}\text { Reproductive barrier between } \\
\text { antibiotic-induced males and females due to } \\
\text { nonreceptivity of females. }\end{array}$ & $\begin{array}{l}\text { Unknown, } \\
\text { but not } \\
\text { Wolbachia }\end{array}$ & Galeopsomyia fausta [91] \\
\hline $\begin{array}{l}\text { Female mating } \\
\text { behaviour (and } \\
\text { anatomy) }\end{array}$ & $\begin{array}{l}\text { Females reluctant to mate and also have } \\
\text { ananatomical alteration: major spermathecal } \\
\text { muscle absent }\end{array}$ & Wolbachia & $\begin{array}{l}\text { Muscidifurax } \\
\text { uniraptor [53] }\end{array}$ \\
\hline Mate choice & $\begin{array}{l}\text { Assortative mating dependent on genotype, } \\
\text { infection status and combination. }\end{array}$ & Wolbachia & $\begin{array}{l}\text { Drosophila } \\
\text { melanogaster [92] }\end{array}$ \\
\hline “ & $\begin{array}{l}\text { Males prefer real females to feminized } \\
\text { genetic males }\end{array}$ & Wolbachia & $\begin{array}{l}\text { Armadillidum } \\
\text { vulgare [93] }\end{array}$ \\
\hline “ & Uninfected females prefer uninfected males & Wolbachia & Tetranychus urticae [21] \\
\hline $\begin{array}{l}\text { Male-male } \\
\text { competition }\end{array}$ & $\begin{array}{l}\text { Infected males are more competitive (more } \\
\text { likely to mate with tester female when in } \\
\text { direct competition) }\end{array}$ & Wolbachia & $\begin{array}{l}\text { Drosophila } \\
\text { melanogaster [73] }\end{array}$ \\
\hline Male mating rate & $\begin{array}{l}\text { Infected males mate more than uninfected } \\
\text { counterparts }\end{array}$ & Wolbachia & $\begin{array}{l}\text { Drosophila melanogaster } \\
\& \text { D. simulans }[94]\end{array}$ \\
\hline “ & $\begin{array}{l}\text { Male ability to mate multiply higher in } \\
\text { species harbouring feminizing symbiont }\end{array}$ & Wolbachia & $\begin{array}{l}\text { Comparative analysis } \\
\text { including } 7 \text { isopod species, } \\
\text { five with feminizing versus } \\
\text { two with CI-inducing } \\
\text { Wolbachia symbionts [95] }\end{array}$ \\
\hline Male fertility & Infected males do not produce mature sperm & Wolbachia & $\begin{array}{l}\text { Muscidifurax uniraptor } \\
\text { [53] }\end{array}$ \\
\hline $\begin{array}{l}\text { Aggregating/ } \\
\text { Lekking }\end{array}$ & $\begin{array}{l}\text { Sex role reversal: females aggregate on } \\
\text { hilltops to attract rare males }\end{array}$ & Wolbachia & Acraea encedon [22] \\
\hline $\begin{array}{l}\text { Female } \\
\text { post-copulatory } \\
\text { behaviour }\end{array}$ & $\begin{array}{l}\text { Influence on offspring sex ratio via } \\
\text { alteration of female post-copulatory position }\end{array}$ & Wolbachia & $\begin{array}{l}\text { Pityohyphantes } \\
\text { phrygianus [96] }\end{array}$ \\
\hline $\begin{array}{l}\text { Oviposition } \\
\text { “ }\end{array}$ & Infected females aggregate offspring & $\begin{array}{l}\text { Wolbachia } \\
\text { Wolbachia }\end{array}$ & $\begin{array}{l}\text { Tetranychus urticae [21] } \\
\text { Encarsia hispida }[97]\end{array}$ \\
\hline “ & $\begin{array}{l}\text { Cured females accept one host type at the } \\
\text { same rate as control females but parasitized } \\
\text { significantly fewer of the other host type. }\end{array}$ & Cardinium & Encarsia pergandiella $[58]$ \\
\hline
\end{tabular}


Table 4. Cont.

\begin{tabular}{|c|c|c|c|}
\hline Behaviours & Effects & Symbionts & Host species (reference) \\
\hline \multicolumn{4}{|l|}{ Reproductive } \\
\hline $\begin{array}{l}\text { Oviposition } \\
\text { substrate } \\
\text { preference }\end{array}$ & $\begin{array}{l}\text { Uninfected flies preferentially lay eggs on } \\
\text { wheat substrate, whereas infected flies do } \\
\text { not exert apparent preference for a particular } \\
\text { substrate }\end{array}$ & Wolbachia & $\begin{array}{l}\text { Drosophila melanogaster } \\
{[72]}\end{array}$ \\
\hline $\begin{array}{l}\text { Oviposition } \\
\text { choice }\end{array}$ & $\begin{array}{l}\text { Infection affects host choice (i.e., number of } \\
\text { eggs laid in particular host type) }\end{array}$ & Cardinium & Encarsia pergandiella [98] \\
\hline \multicolumn{4}{|l|}{ Non-reproductive } \\
\hline $\begin{array}{l}\text { Larval } \\
\text { competitive ability }\end{array}$ & $\begin{array}{l}\text { Offspring of infected females are more } \\
\text { competitive }\end{array}$ & Wolbachia & $\begin{array}{l}\text { Drosophila } \\
\text { melanogaster [20] }\end{array}$ \\
\hline Dispersal & $\begin{array}{l}\text { Infected females are less likely to adopt } \\
\text { long-range dispersal behaviour (ballooning) }\end{array}$ & Rickettsia & Erigone atra [19] \\
\hline
\end{tabular}

In many of the cases described above a direct link is established between the infecting bacterium and the behaviour itself. Wild-type behaviour is restored by curing the host of its infection using antibiotics or by treatment at elevated temperatures. In this sense, the behavioural response is a direct result of bacterial interaction with its host and the behavioural change itself may be one of the mechanisms through which increased bacterial transmission is achieved. One illustrative example is the aggregation of eggs by spider mites [21], which is proposed to increase the chances of mating between individuals carrying compatible bacterial strains. Behavioural changes that increase the competitive ability of offspring are also likely to increase bacterial transmission relative to uninfected individuals [20]. The precise mechanisms underlying these behavioural effects on the host remain unknown but it is interesting to note that in the case of the linyphiid spider bacteria were found specifically in regions of nervous tissue associated with motor function [19].

In addition to direct influences of bacteria on the behaviour of their host there are also instances when host behaviour is altered indirectly, for example in response to manipulation of the population sex ratio. One extreme example of this is observed in a species of Acraea butterfly where a male killing endosymbiont results in a highly female-biased sex ratio [22]. In response to this there is sexrole reversal of lekking behaviour where females form leks around the remaining males. The case of female lekking in Acraea represents an extreme and rapid behavioural shift in response to a bacterial phenotype. Similarly, strongly female-biased sex ratios caused by Wolbachia infection in another butterfly, Hypolimnas bolina, lead to increased female mating frequency, and simultaneously to increased male fatigue associated with more prudent sperm investment per mating [23]. However there may be many more instances of subtle (and potentially transient) shifts in behaviour that might also have long-term consequences. For example, dispersal of female Erigone atra spiders is shown to be under the influence of a Rickettsia infection [19]. This is expected to result in localised perturbations of the sex ratio within the spider meta-population and as a consequence, localised variation in the strength of selection acting on traits that are sex-ratio dependent such as those involved in male-male competition or in the levels of male investment in attracting a mate. 


\section{The Evolutionary Consequences of Endosymbiont Driven Changes in Arthropod Behaviour}

Perhaps the ultimate evolutionary novelty is the creation of a new species. Endosymbiont infections have been shown to be mechanisms by which gene flow can be restricted, for example through causing cytoplasmic incompatibility. Such restrictions on gene flow, even if transient or spatially restricted, may be an important component of the speciation process in particular cases [4,24]. It is unclear whether endosymbiont driven shifts in behaviour alone can also ultimately create new species although traits such as reduced dispersal e.g., as shown in the spider Erigone atra [19], likely reduce genetic exchange within the wider meta-population. Such effects, even if transient and/or spatially restricted, potentially contribute to the development of reproductive isolation and thus influence the broader process of adaptation and speciation.

Whilst the hypothesis that endosymbiont driven changes in behaviour can lead directly to reproductive isolation is difficult to test, it is certainly true that changes in both reproductive and non-reproductive behaviours such as mating preference or dispersal likely influence genetic diversity at a local scale. For instance restriction in the number of successfully reproducing individuals via male-killing or CI will lower the effective population size [25]. Such impacts on population size and the various impacts on reproductive traits will have further consequences for the local intensity and dynamics of sexual selection and conflict [26-28]. Similarly, a skewed population sex ratio will also lead to shifts in the strength and shape of sexual selection and as a consequence altered female behaviour [22,23]. Changes in mating preference may also alter the predicted linkage disequilibria amongst physically unlinked loci. Migrants canalso perturb linkage disequilibria if incoming genotypes differ from those in the resident population. These and other factors influence the ability of populations locally to adapt through natural selection in two ways. First, incoming genes or genotypes may be maladapted to the local environment. Second, changes in effective population size affect the sensitivity of local populations to the effects of random genetic drift.

Endosymbiont shifts in arthropod behaviour potentially reduce the ability of a population to adapt and persist if the outcome is reduced intraspecific variability, but in certain instances they may also favour population expansion, for instance through inducing parthenogenesis or by altering female mating rate [29]. Such rapid shifts can allow a population to expand into an empty niche. Shifts in behaviour caused by endosymbionts may also promote and maintain rather than reduce variation within a population, for instance if they increase levels of assortative mating that reduce the loss of rarer variants.

In many cases it is difficult to assess whether or not there has been sufficient time since an infection was acquired for the host and bacterium to reach equilibrium. Examples that illustrate that equilibrium has not always been reached include that of Hypolimnas butterflies in Polynesia, where the frequency of a male-killer decreased rapidly over a short time-frame due to the proliferation of a suppressor gene [30-32]. Assessing whether equilibrium has or has not been reached is sometimes further complicated by the many instances where there are co-infecting endosymbionts that may not have been acquired at the same time and that have different, potentially conflicting phenotypes where some increase host fitness and others appear detrimental [99]. Changes in host behaviour (and other host traits) that result directly from an infection or as a response to bacterial phenotypes such as sex ratio bias, are thus not only potentially transient but also rapidly changing. The magnitude of the effects that they have had at a population level may thus be difficult to establish. 


\section{Conclusions}

Studies of individual species indicate that endosymbionts are a potential source of behavioural modification of their arthropod hosts either directly through their interaction with the host or indirectly as a consequence of perturbations in sex ratio. Endoymbionts may influence precopulatory reproductive isolation by altering preferences and mating rates of male and female hosts. Behavioural changes induced by endosymbionts can also potentially alter levels of genetic variation within species and the degree of population subdivision. They thereby influence the potential of a species to adapt in response to changes in the environment.

\section{Acknowledgments}

The authors would like to thank the Swiss National Science Foundation (Ambizione grants PZ00P3-121777 and PZ00P3-137514 to OYM) and the University of Nottingham and the Research Councils UK for a Fellowship to SLG.

\section{References}

1. Schmid-Hempel, P. Evolutionary Parasitology: The Integrated Study of Infections, Immunology, Ecology, and Genetics; Oxford University Press: Oxford, UK, 2011.

2. Thomas, F.; Adamo, S.; Moore J. Parasitic manipulation: Where are we and where should we go? Behav. Process. 2005, 68, 185-199.

3. Perrot-Minnot, M.J.; Cézilly, F. Parasite-Induced Behavioral Change: Mechanisms. In Encyclopedia of Animal Behavior; Breed, M., Moore, J., Eds.; Elsevier Press: Oxford, UK, 2010; pp. 618-627.

4. Engelstädter, J.; Hurst, G.D.D. The ecology and evolution of microbes that manipulate host reproduction. Annu. Rev. Ecol. Evol. Syst. 2009, 40, 127-149.

5. Charlat, S.; Hurst, G.D.D.; Mercot, H. Evolutionary consequences of Wolbachia infections. Trends Genet. 2003, 19, 217-223.

6. Hilgenboecker, K.; Hammerstein, P.; Schlattmann, P.; Telschow, A.; Werren, J.H. How many species are infected with Wolbachia? A statistical analysis of current data. FEMS Microbiol. Lett. 2008, 281, 215-220.

7. Goodacre, S.L.; Martin, O.Y.; Thomas, C.F.G.; Hewitt, G.M. Wolbachia and other endosymbiont infections in spiders. Mol. Ecol. 2006, 15, 517-527.

8. Mateos, M.; Castrezana, S.J.; Nankivell, B.J.; Estes, A.M.; Markow, T.A.; Moran, N.A. Heritable endosymbionts of Drosophila. Genetics 2006, 174, 363-376.

9. Martin, O.Y.; Gubler, A.; Wimmer, C.; Germann, C.; Bernasconi, M.V. Infections with Wolbachia and Spiroplasma in the Scathophagidae and other Muscoidea. Infect. Genet. Evol. 2012, (in press).

10. Duron, O.; Bouchon, D.; Boutin, S.; Bellamy, L.; Zhou, L.Q.; Engelstädter, J.; Hurst, G.D.D. The diversity of reproductive parasites among arthropods: Wolbachia do not walk alone. BMC Biol. 2008, 6, doi:10.1186/1741-7007-6-27. 
11. Martin, O.Y.; Goodacre, S.L. Widespread infections by the bacterial endosymbiont Cardinium in arachnids. J. Arachnol. 2009, 37, 106-108.

12. Pannebakker, B.A.; Loppin, B.; Elemans, C.P.; Humblot, L.; Vavre, F. Parasitic inhibition of cell death facilitates symbiosis. Proc. Natl. Acad. Sci. USA 2007, 104, 213-215.

13. Degnan, P.; Yub, Y.; Sisneros, N.; Wing, R.A.; Moran, N.A. Hamiltonella defensa, genome evolution of protective bacterial endosymbiont from pathogenic ancestors. Proc. Natl. Acad. Sci. USA 2009, 106, 9063-9068.

14. Vorburger, C.; Sandrock, C.; Gouskov, A.; Castañeda, L.E.; Ferrari, J. Genotypic variation and the role of defensive endosymbionts in an all-parthenogenetic host-parasitoid interaction. Evolution 2009, 63, 1439-1450.

15. Himler, A.G.; Adachi-Hagimori, T.; Bergen, J.E.; Kozuch, A.; Kelly, S.E.; Tabashnik, B.E.; Chiel, E.; Duckworth, V.E.; Dennehy, T.J.; Zchori-Fein, E.; et al. Rapid spread of a bacterial symbiont in an invasive whitefly is driven by fitness benefits and female bias. Science 2011, 332, 254-256.

16. Jaenike, J. Spontaneous emergence of a new Wolbachia phenotype. Evolution 2007, 61, 2244-2252.

17. Fukatsu, T.; Tsuchida, T.; Nikoh, N.; Koga, R. Spiroplasma symbiont of the pea aphid, Acyrthosiphon pisum (Insecta: Homoptera). Appl. Environ. Microbiol. 2001, 67, 1284-1291.

18. Caspi-Fluger, A.; Inbar, M.; Mozes-Daube, N.; Mouton, L.; Hunter, M.S.; Zchori-Fein, E. Rickettsia 'in' and 'out': Two different localization patterns of a bacterial symbiont in the same insect species. PLoS One 2011, 6, doi:10.1371/journal.pone.0021096.

19. Goodacre, S.L., Martin, O.Y.; Bonte, D.; Hutchings, L.; Woolley, C.; Ibrahim, K.; Thomas, C.F.G.; Hewitt, G.M. Microbial modification of host long-distance dispersal capacity. BMC Biol. 2009, 7, 32, doi:10.1186/1741-7007-7-32.

20. Alexandrov, I.D.; Alexandrova, M.V.; Goryacheva, I.I.; Roshchina, N.V.; Shaikevich, E.V.; Zakharov, I.A. Elimination of endosymbiont Wolbachia specifically decreases competitive ability and longevity of females from laboratory strain of Drosophila melanogaster. Russ. J. Genet. 2007, 43, 1147-1152.

21. Vala, F.; Egas, M.; Breeuwer, J.A.J.; Sabelis, M.W. Wolbachia affects oviposition and mating behaviour of its spider mite host. J. Evol. Biol. 2004, 17, 692-700.

22. Jiggins, F.M.; Hurst, G.D.D.; Majerus, M.E.N. Sex-ratio-distorting Wolbachia causes sex-role reversal in its butterfly host. Proc. Biol. Sci. 2000, 267, 69-73.

23. Charlat, S.; Reuter, M.; Dyson, E.A.; Hornett, E.A.; Duplouy, A.M.; Davies, N.; Roderick, G.K.; Wedell, N.; Hurst, G.D. Male killing bacteria trigger a cycle of increasing male fatigue and female promiscuity. Curr. Biol. 2007, 17, 273-277.

24. Hurst, G.D.D.; Werren, J.H. The role of selfish genetic elements in eukaryotic evolution. Nat. Rev. Genet. 2001, 2, 597-606.

25. Engelstädter, J. The effective size of populations infected with cytoplasmic sex-ratio distorters. Genetics 2010, 186, 309-320.

26. Gavrilets, S. Rapid evolution of reproductive barriers driven by sexual conflict. Nature 2000, 403, 886-889. 
27. Martin, O.Y.; Hosken, D.J. The evolution of reproductive isolation through sexual conflict. Nature 2003, 423, 979-982.

28. Hayashi, T.I.; Marshall, J.L.; Gavrilets, S. The dynamics of sexual conflict over mating rate with endosymbiont infection that affects reproductive phenotypes. J. Evol. Biol. 2007, 20, 2154-2164.

29. Huigens, M.E.; Stouthamer, R. Parthenogenesis Associated with Wolbachia. In Insect Symbiosis; Bourtzis, K., Miller, T.A., Eds.; CRC Press: Boca Raton, FL, USA, 2003; pp. 247-266.

30. Dyson, E.A.; Hurst, G.D.D. Persistence of an extreme sex-ratio bias in a natural population. Proc. Natl. Acad. Sci. USA 2004, 101, 6520-6523.

31. Charlat, S.; Hornett, E.A.; Fullard, J.H.; Davies, N.; Roderick, G.K.; Wedell, N.; Hurst, G.D.D. Extraordinary flux in sex ratio. Science 2007, 317, doi:10.1126/science.1143369.

32. Martin, O.Y.; Gage, M.J.G. Evolutionary conflicts: Rapid suppression of a male-killer. Curr. Biol. 2007, 17, R849-R851.

33. Jiggins, F.M.; Hurst, G.D.D.; Majerus, M.E.N. Sex ratio distorsion in Acraea encedon (Lepidoptera: Nymphalidae) is caused by a male-killing bacterium. Heredity 1998, 81, 87-91.

34. Zeh, D.W.; Zeh, J.A.; Bonilla, M.M. Wolbachia, sex ratio bias and apparent male killing in the harlequin beetle riding pseudoscorpion. Heredity 2005, 95, 41-49.

35. Vanthournout, B.; Swaegers, J.; Hendrickx, F. Spiders do not escape reproductive manipulations by Wolbachia. BMC Evol. Biol. 2011, 11, doi:10.1186/1471-2148-11-15.

36. Lawson, E.T.; Mousseau, T.A.; Klaper, R.; Hunter, M.D.; Werren, J.H. Rickettsia associated with male-killing in a buprestid beetle. Heredity 2001, 86, 497-505.

37. Werren, J.H.; Hurst, G.D.D.; Zhang, W.; Breeuwer, J.A.; Stouthamer, R.; Majerus, M.E.N. Rickettsial relative associated with male killing in the ladybird beetle (Adalia bipunctata). J. Bacteriol. 1994, 176, 388-394.

38. Von der Schulenburg, J.H.G.; Habig, M.; Sloggett, J.J.; Webberley, K.M.; Bertrand, D.; Hurst, G.D.D.; Majerus, M.E.N. Incidence of male-killing Rickettsia spp. (alpha-proteobacteria) in the ten-spot ladybird beetle Adalia decempunctata L. (Coleoptera: Coccinellidae). Appl. Environ. Microb. 2001, 67, 270-277.

39. Hurst, G.D.D.; Jiggins, F.M.; von der Schulenburg, J.H.G.; Bertrand, D.; West, S.A.; Goriacheva, I.I.; Zakharov, I.A.; Werren, J.H.; Stouthamer, R.; Majerus, M.E.N. Male-killing Wolbachia in two species of insect. Proc. R. Soc. Lond. B 1999, 266, 735-740.

40. Tinsley, M.C.; Majerus, M.E.N. A new male-killing parasitism: Spiroplasma bacteria infect the ladybird beetle Anisosticta novemdecimpunctata (Coleoptera: Coccinellidae). Parasitology 2006, 132, 757-765.

41. Majerus, T.M.O.; Majerus, M.E.N.; Knowles, B.; Wheeler, J.; Bertrand, D.; Kuznetsov, V.N.; Ueno, H.; Hurst, G.D.D. Extreme variation in the prevalence of inherited male-killing microorganisms between three populations of Harmonia axyridis (Coleoptera: Coccinellidae). Heredity 1998, 81, 683-691.

42. Jiggins, F.M.; Hurst, G.D.D.; Jiggins, C.D.; von der Schulenburg, J.H.; Majerus, M.E.N. The butterfly Danaus chrysippus is infected by a male-killing Spiroplasma bacterium. Parasitology 2000, 120, 439-446. 
43. Williamson, D.L.; Sakaguchi, B.; Hackett, K.J.; Whitcomb, R.F.; Tully, J.G.; Carle, P.G.; Bove, J.M.; Adams, J.R.; Konai, M.; Henegar, R.B. Spiroplasma poulsonii sp. nov., a new species associated with male lethality in Drosophila willistoni, a neotropical species of fruit fly. Int. J. Syst. Bacteriol. 1999, 49, 611-618.

44. Gherna, R.L.; Werren, J.H.; Weisburg, W.; Cote, R.; Woese, C.R.; Mandelco, L., Brenner, D.J. Arsenophonus nasoniae gen. nov., sp. nov., the causative agent of the Son-killer trait in the parasitic wasp Nasonia vitripennis. Int. J. Syst. Bacteriol. 1991, 41, 563-565.

45. Hurst, G.D.D.; Hammarton, T.C.; Bandi, C.; Majerus, T.M.O.; Bertrand, D.; Majerus, M.E.N. The diversity of inherited parasites of insects: The male-killing agent of the ladybird beetle Coleomegilla maculata is a member of the Flavobacteria. Genet. Res. 1997, 70, 1-6.

46. Hurst, G.D.D.; Bandi, C.; Sacchi, L.; Cochrane, A.; Bertrand, D.; Karaca, I.; Majerus, M.E.N. Adonia variegata (Coleoptera: Coccinellidae) bears maternally inherited Flavobacteria that kill males only. Parasitology 1999, 118, 125-134.

47. Juchault, P.; Legrand, J.J. Sex determination and monogeny in terrestrial Isopods Armadillidium vulgare (Latreille, 1804) and Armadillidium nasatum (Budde-Lund, 1885). Monit. Zool. Ital. (N.S.) Monogr. 1989, 4, 359-375.

48. Rousset, F.; Bouchon, D.; Pintureau, B.; Juchault, P.; Solignac, M. Wolbachia endosymbionts responsible for various alterations of sexuality in arthropods. Proc. R. Soc. Lond. B 1992, 250, 91-98.

49. Hiroki, M.; Kato, Y.; Kamito, T.; Miura, K. Feminization of genetic males by a symbiotic bacterium in a butterfly, Eurema hecabe (Lepidoptera: Pieridae). Naturwissenschaften 2002, 89, $167-170$.

50. Weeks, A.R.; Marec, F.; Breeuwer, J.A. A mite species that consists entirely of haploid females. Science 2001, 292, 2479-2482.

51. Chigira, A.; Miura, K. Detection of 'Candidatus Cardinium' bacteria from the haploid host Brevipalpus californicus (Acari: Tenuipalpidae) and effect on the host. Exp. Appl. Acarol. 2005, 37, 107-116.

52. Stouthamer, R.; Breeuwer, J.A.J.; Luck, R.F.; Werren, J.H. Molecular identification of microorganisms associated with parthenogenesis. Nature 1993, 361, 66-68.

53. Gottlieb, Y.; Zchori-Fein, E. Irreversible thelytokous reproduction in Muscidifurax uniraptor. Entomol. Exp. Appl. 2001, 100, 271-278.

54. Arakaki, N.; Hiroaki, N.; Yamagishi, K. Wolbachia-induced parthenogenesis in the egg parasitoid Telenomus nawai. Entomol. Exp. Appl. 2000, 96, 177-184.

55. Pijls, J.W.A.M.; van Steenbergen, H.J.; van Alphen, J.J.M. Asexuality cured: The relations and differences between sexual and asexual Apoanagyrus diversicornis. Heredity 1996, 76, 506-513.

56. Werren, J.H.; Zhang, W.; Guo, L.R. Evolution and phylogeny of Wolbachia: Reproductive parasites of arthropods. Proc. R. Soc. Lond. B 1995, 251, 55-63.

57. Zchori-Fein, E.; Faktor, O.; Zeidan, M.; Gottlieb, Y.; Czosnek, H.; Rosen, D. Parthenogenesis-inducing microorganisms in Aphytis (Hymenoptera: Aphelinidae). Insect Mol. Biol. 1995, 4, 173-178. 
58. Zchori-Fein, E.; Gottlieb, Y.; Kelly, S.E.; Brown, J.K.; Wilson, J.M.; Karr, T.L.; Hunter, M.S. A newly discovered bacterium associated with parthenogenesis and a change in host selection behavior in parasitoid wasps. Proc. Natl. Acad. Sci. USA 2001, 98, 12555-12560.

59. Zchori-Fein, E.; Perlman, S.J.; Kelly, S.E.; Katzir, N.; Hunter, M.S. Characterization of a 'Bacteroidetes symbiont' in Encarsia wasps (Hymenoptera: Aphelinidae): Proposal of 'Candidatus cardinium hertigii'. Int. J. Syst. Evol. Microbiol. 2004, 54, 961-968.

60. Provencher, L.M.; Morse, G.E.; Weeks, A.R.; Normark, B.B. Parthenogenesis in the Aspidiotus nerii complex (Hemiptera: Diaspididae): A single origin of a worldwide, polyphagous lineage associated with Cardinium bacteria. Ann. Entomol. Soc. Am. 2005, 98, 629-635.

61. Hagimori, T.; Abe, Y.; Date, S.; Miura, K. The first finding of a Rickettsia bacterium associated with parthenogenesis induction among insects. Curr. Microbiol. 2006, 52, 97-101.

62. Wade, M.J.; Stevens, L. Microorganism mediated reproductive isolation in flour beetles (genus Tribolium). Science 1985, 227, 527-528.

63. Yen, J.H.; Barr, A.R. The etiological agent of cytoplasmic incompatibility in Culex pipiens. J. Invertebr. Pathol. 1973, 22, 242-250.

64. Gotoh, T.; Noda, H.; Ito, S. Cardinium symbionts cause cytoplasmic incompatibility in spider mites. Heredity 2007, 98, 13-20.

65. Ros, V.I.D.; Breeuwer, J.A.J. The effects of, and interactions between, Cardinium and Wolbachia in the doubly infected spider mite Bryobia sarothamni. Heredity 2009, 102, 413-422.

66. Hunter, M.S.; Perlman, S.J.; Kelly, S.E. A bacterial symbiont in the Bacteroidetes induces cytoplasmic incompatibility in the parasitoid wasp Encarsia pergandiella. Proc. R. Soc. Lond. B 2003, 270, 2185-2190.

67. Wade, M.J.; Chang, N.W. Increased male fertility in Tribolium confusum beetles after infection with the intracellular parasite Wolbachia. Nature 1995, 373, 72-74.

68. Weeks, A.R.; Stouthamer, R. Increased fecundity associated with infection by a Cytophaga-like intracellular bacterium in the predatory mite, Metaseiulus occidentalis. Proc. R. Soc. Lond. B 2004, 271, S193-S195.

69. Vavre, F.; Girin, C.; Bouletreau, M. Phylogenetic status of a fecundity-enhancing Wolbachia that does not induce thelytoky in Trichogramma. Mol. Biol. Evol. 1999, 8, 67-72.

70. Dobson, S.; Marsland, E.; Rattanadechakul, W. Mutualistic Wolbachia infection in Aedes albopictus: Accelerating cytoplasmic drive. Genetics 2002, 160, 1087-1094.

71. Miller, W.J.; Ehrman, L.; Schneider, D. Infectious speciation revisited: Impact of symbiont-depletion on female fitness and mating behavior of Drosophila paulistorum. PLoS Pathog. 2010, 6, doi:10.1371/journal.ppat.1001214.

72. Champion de Crespigny, F.E.C.; Wedell, N. Wolbachia infection reduces sperm competitive ability in an insect. Proc. R. Soc. Lond. B 2006, 273, 1455-1458.

73. Panteleev, D.Y.; Goryacheva, I.I.; Andrianov, B.V.; Reznik, N.L.; Lazebny, O.E.; Kulikov, A.M. Endosymbiotic bacteria Wolbachia increase non-specific resistance to entomopathogens and changes behavior in Drosophila melanogaster. Russ. J. Genet. 2007, 43, 1066-1069.

74. Bian, G.; Xu, Y.; Lu, P.; Xie, Y.; Xi, Z. The endosymbiotic bacterium Wolbachia induces resistance to Dengue virus in Aedes aegypti. PLoS Pathog. 2010, 6, doi:10.1371/ journal.ppat.1000833. 
75. Teixeira, L.; Ferreira, A.; Ashburner, M. The bacterial symbiont Wolbachia induces resistance to RNA viral infections in Drosophila melanogaster. PLoS Biol. 2008, 6, doi:10.1371/ journal.pbio.1000002.

76. Hedges, L.M.; Brownlie, J.C.; O’Neill, S.L.; Johnson, K.N. Wolbachia and virus protection in insects. Science 2008, 322, doi:10.1126/science.1162418.

77. Osborne, S.E.; Leong, Y.S.; O’Neill, S.L.; Johnson, K.N. Variation in antiviral protection mediated by different Wolbachia strains in Drosophila simulans. PLoS Pathog. 2009, 5, doi:10.1371/journal.ppat.1000656.

78. Fry, A.; Rand, D. Wolbachia interactions that determine Drosophila melanogaster survival. Evolution 2002, 56, 1976-1981.

79. Wilkes, T.E.; Duron, O.; Darby, A.C.; Hypsa, V.; Nováková, E.; Hurst, G.D.D. The Genus Arsenophonus. In Manipulative Tenants: Bacteria Associated with Arthropods; Zchori-Fein, E., Bourtzis, K., Eds.; CRC Press: Boca Raton, FL, USA, 2011; pp. 225-44.

80. Allen, J.M.; Reed, D.L.; Perotti, M.A.; Braig, H.R. Evolutionary relationships of "Candidatus Riesia spp.," endosymbiotic Enterobacteriaceae living within hematophagous primate lice. Appl. Environ. Microbiol. 2007, 73, 1659-1664.

81. Perotti, M.A.; Allen, J.M.; Reed, D.L.; Braig, H.R. Host-symbiont interactions of the primary endosymbiont of human head and body lice. FASEB J. 2007, 21, 1058-1066.

82. Hosokawa, T.; Koga, R.; Kikuchi, Y.; Meng, X.-Y; Fukatsu, T. Wolbachia as a bacteriocyte-associated nutritional mutualist. Proc. Natl. Acad. Sci. USA 2010, 107, 769-774.

83. Brownlie, J.C.; Cass, B.N.; Riegler, M.; Witsenburg, J.J.; Iturbe-Ormaetxe, I.; McGraw, E.A.; O'Neill, S.L. Evidence for metabolic provisioning by a common invertebrate endosymbiont, Wolbachia pipientis, during periods of nutritional stress. PLoS Pathog. 2009, 5, doi:10.1371/journal.ppat.1000368.

84. Brumin, M.; Kontsedalov, S.; Ghanim, M. Rickettsia influences thermotolerance in the whitefly Bemisia tabaci B biotype. Insect Sci. 2011, 18, 57-66.

85. Xie, J.; Vilchez, I.; Mateos, M. Spiroplasma bacteria enhance survival of Drosophila hydei attacked by the parasitic wasp Leptopilina heterotoma. PLoS One 2010, 5, doi:10.1371/journal.pone.0012149.

86. Kontsedalov, S.; Zchori-Fein, E.; Chiel, E.; Gottlieb, Y.; Inbar, M.; Ghanim, M. The presence of Rickettsia is associated with increased susceptibility of Bemisia tabaci (Homoptera: Aleyrodidae) to insecticides. Pest Manag. Sci. 2008, 64, 789-792.

87. Ghanim, M.; Kontsedalov, S. Susceptibility to insecticides in the Q biotype of Bemisia tabaci is correlated with bacterial symbiont densities. Pest Manag. Sci. 2009, 65, 939-942.

88. Sasaki, T.; Kubo, T.; Ishikawa, H. Interspecific transfer of Wolbachia between two lepidopteran insects expressing cytoplasmic incompatibility: A Wolbachia variant naturally infecting Cadra cautella causes male killing in Ephestia kuehniella. Genetics 2002, 162, 1313-1319.

89. Bouchon, D.; Rigaud, T.; Juchault, P. Evidence for widespread Wolbachia infection in isopod crustaceans: Molecular identification and host feminization. Proc. R. Soc. Lond. B 1998, 265, 1081-1090.

90. Fialho, R.F.; Stevens, L. Male-killing Wolbachia in a flour beetle. Proc. R. Soc. Lond. B 2000, 267, 1469-1473. 
91. Argov, Y.; Gottlieb, Y.; Amin-Spector, S.; Zchori-Fein, E. Possible symbiont-induced thelytoky in Galeopsomyia fausta, a parasitoid of the citrus leafminer Phyllocnistis citrella. Phytoparasitica 2000, 28, 212-218.

92. Markov, A.V.; Lazebny, O.E.; Goryacheva, I.I.; Antipin, M.I.; Kulikov, A.M. Symbiotic bacteria affect mating choice in Drosophila melanogaster. Anim. Behav. 2009, 77, 1011-1017.

93. Moreau, J.; Bertin, A.; Caubet, Y.; Rigaud, T. Sexual selection in an isopod with Wolbachia-induced sexual reversal: Males prefer real females. J. Evol. Biol. 2001, 14, 388-394.

94. Champion de Crespigny, F.E.C.; Pitt, T.D.; Wedell, N. Increased male mating rate in Drosophila is associated with Wolbachia infection. J. Evol. Biol. 2006, 19, 1964-1972.

95. Moreau, J.; Rigaud, T. Variable male potential rate of reproduction: High male mating capacity as an adaptation to parasite-induced excess of females? Proc. R. Soc. Lond. B 2003, 270, 1535-1540.

96. Gunnarsson, B.; Goodacre, S.L.; Hewitt, G.M. Sex ratio, mating behaviour and Wolbachia infections in a sheetweb spider. Biol. J. Linn. Soc. 2009, 98, 181-186.

97. Hunter, M.S. The influence of parthenogenesis-inducing on the oviposition behavior and sex-specific developmental requirements of autoparasitoid wasps. J. Evol. Biol. 1999, 12, 765-741.

98. Kenyon, S.G.; Hunter, M.S. Manipulation of oviposition choice of the parasitoid wasp, Encarsia pergandiella, by the endosymbiotic bacterium Cardinium. J. Evol. Biol. 2007, 20, 707-716.

99. Zhong, J.; Jasinskas, A.; Barbour, A.G. Antibiotic treatment of the tick vector Amblyomma americanum reduced reproductive fitness. PLoS One 2007, 2, doi:10.1371/journal.pone.0000405.

(C) 2012 by the authors; licensee MDPI, Basel, Switzerland. This article is an open access article distributed under the terms and conditions of the Creative Commons Attribution license (http://creativecommons.org/licenses/by/3.0/). 